\begin{tabular}{|c} 
Ambiente \& Água - An Interdisciplinary Journal of Applied Science \\
ISSN 1980-993X - doi:10.4136/1980-993X \\
www.ambi-agua.net \\
E-mail: ambi.agua@gmail.com
\end{tabular}

\title{
Assessment of digital elevation models to obtain morphometric characteristics in relief transition region
}

\author{
ARTICLES doi:10.4136/ambi-agua.2280
}

Received: 21 May 2018; Accepted: 01 Dec. 2018

\begin{abstract}
Kevin Nunes Ficher ${ }^{1(\mathbb{D})}$; Donizete dos Reis Pereira ${ }^{\text {*(D) }}$; Josiane Silva Oliveira ${ }^{1(\mathbb{D})}$ André Quintão de Almeida ${ }^{2}$; ; Eduardo Morgan Uliana ${ }^{3}$ (D)

${ }^{1}$ Universidade Federal de Viçosa (UFV), Florestal, MG, Brasil

Instituto de Ciências Agrárias (IAF). E-mail: kevin.nficher@gmail.com,donizete.pereira@ufv.br, josianerso@gmail.com

${ }^{2}$ Universidade Federal do Sergipe (UFS), São Cristovão, SE, Brasil

Departamento de Engenharia Agrícola (DEAGRI). E-mail: andreqa@gmail.com

${ }^{3}$ Universidade Federal de Mato Grosso (UFMT), Sinop, MT, Brasil

Instituto de Ciências Agrárias e Ambientais (ICAA). E-mail: morganuliana@gmail.com

*Corresponding author
\end{abstract}

\begin{abstract}
The purpose of this study was to evaluate the performance of Digital Elevation Models (DEMs) in the morphometric characterization of a basin located in a transitional region between the São Francisco Plateau, São Francisco Depression and Espinhaço Range reliefs. For the study, four DEMs were generated by interpolation of the SRTM data and topographic maps, using the Topo To Raster interpolator with and without mapped hydrography support, available in ArcGIS ${ }^{\circledR} 9.3$ software. Another DEM was obtained from the SRTM original data. From the generated DEMs, the morphometric characteristics of the basin were determined and compared to those obtained from topographic maps, denominated reference (REF), by means of percentage errors. The evaluation was also performed in a qualitative way, comparing the drainage and the basin delineations. In general, the DEMs obtained with the support of the mapped hydrography (SRTM-TRH and CT-TRH) provided the best results, with small errors, mainly for the main morphometric characteristics of the basin, drainage area and main river length, which ranged from 0.38 to $1.12 \%$ and 5.28 to $7.07 \%$, respectively. On the other hand, the DEMs generated without the support of the mapped hydrography (SRTM-O, SRTM-TR and CT-TR) presented major errors mainly in determining the drainage area and length of the main river, which varied from 18.1 to $26.6 \%$ and 26.7 to $34.4 \%$, respectively. These occurred due to a deviation of the main river in the São Franciscana Depression region, which allows us to conclude on the necessity and importance of evaluating DEMs before their use.
\end{abstract}

Keywords: srtm, topographical maps, topo to raster.

\section{Avaliação de modelos digitais de elevação para obtenção de características morfométricas em região de transição de relevos}

\section{RESUMO}

Objetivou-se com este estudo, avaliar o desempenho de MDEs na caracterização morfométrica de uma bacia hidrográfica situada em região de transição entre os relevos Planalto 
São Franciscana, Depressão São Franciscana e Serra do Espinhaço. Para o estudo, foram gerados quatro MDEs por interpolação dos dados do SRTM e de cartas topográficas, utilizando o interpolador Topo To Raster com e sem suporte da hidrografia mapeada, disponível no software ArcGIS ${ }^{\circledR}$ 9.3. Outro MDE foi obtido a partir dos dados originais do SRTM. A partir dos MDEs gerados, determinaram-se as características morfométricas da bacia e comparou-as àquelas obtidas de cartas topográficas, denominadas de referência (REF), por meio da determinação de erros percentuais. A avaliação também foi realizada de maneira qualitativa comparando as drenagens e as delimitações da bacia. De um modo geral, os MDEs obtidos com o suporte da hidrografia mapeada (SRTM-TRH e CT-TRH) proporcionaram os melhores resultados, com pequenos erros, principalmente, para as principais características morfométricas da bacia, área de drenagem e comprimento do rio principal, os quais variaram de 0,38 a $1,12 \%$ e 5,28 a 7,07\%, respectivamente. Por outro lado, os MDEs gerados sem o suporte da hidrografia mapeada (SRTM-O, SRTM-TR e CT-TR) apresentaram grandes erros, principalmente, na determinação da área de drenagem e comprimento do rio principal, os quais variaram de 18,1 a 26,6\% e 26,7 a 34,4\%, respectivamente. Esses ocorreram em razão de um desvio do rio principal na região da Depressão São Fransciscana, o que nos permite concluir sobre a necessidade e importância de se avaliar MDEs antes de sua utilização.

Palavras-chave: cartas topográficas, srtm, topo to raster.

\section{INTRODUCTION}

The knowledge of morphometric characteristics of watersheds is fundamental in the development of hydrological studies for the purposes of better planning and management of water resources (Aher et al., 2014). These characteristics are important for: the estimation of the runoff depth and time of concentration of the flow in the basin (Silva et al., 2006; Abdulkareem et al., 2018; Mudashiru et al., 2018); the regionalization of flows (Fioreze et al., 2008; Bassiouni et al., 2016); hydrological modeling (Chaplot et al., 2006; Cecílio et al., 2013; Meraj et al., 2015; Abdulkareem et al., 2018); and as indicators of the degree of vulnerability of the basin to phenomena such as floods and soil erodibility (Esper Angillieri, 2008; Gebrehiwot et al., 2011; Ameri et al., 2018).

Currently, the morphometric characteristics of basins are determined automatically by means of the processing of digital data of elevation of the terrain, using tools of geoprocessing and Geographic Information Systems (GIS) (Cunha and Bacani, 2016). The digital terrain elevation information is represented by a numerical structure of data corresponding to altitude spatial distribution and of the terrain surface, called Digital Elevation Model (DEM) (Oliveira et al., 2010).

The DEMs may be obtained by remote sensing data or generated from the interpolation of point topographical data and contour lines extracted from topographic maps (Oliveira et al., 2010; Cecílio et al., 2013). In Brazil, the most common data source for the generation of the DEMs are the contour lines, and of supplementary form, the hydrography and the elevation points obtained from topographic maps. However, the scarcity of such data in certain places, makes the information from images and remote sensors of great importance for the generation of these models (Chagas et al., 2010).

The quality of the DEMs is fundamental to the success of hydrological studies, especially when it comes to modeling (Chaplot et al., 2006), because depending on the characteristics of the DEM (scale, resolution and origin), the automatic delineation of a basin and, consequently, its morphometric characteristics, may differ significantly (Pires et al., 2005; Alcaraz et al., 2009; Seyler et al., 2009; Cecílio et al., 2013). Thus, several studies have been conducted to analyze, compare and update the information on the earth's surface, obtained by means of 
remote sensing data or by cartographic bases.

In this sense, Woodrow et al. (2016) analyzed the effects of resolution, origin and conditioning techniques of DEM on spatial and statistical distribution of field-scale hydrological attributes for a 12,000 ha agricultural watershed in southwestern Ontario, Canada. The basins were delimited using the surface drainages modeled from LiDAR data, interpolated in DEMs of resolution of 1, 5 and $10 \mathrm{~m}$, and a photogrammetric DEM of $10 \mathrm{~m}$ resolution. The results showed that the variation in the resolution of the DEM resulted in significant differences in the spatial and statistical distributions of the drainage areas and in the downslope flowpath length. LiDAR DEMs are derived from airborne laser surveys and because they are high resolution they have had a major impact on topographic analysis of the earth's surface in many countries.

The effects of the resolution of the DEM on surface drainage were also investigated by Ariza-Villaverde et al. (2015), when analyzing the influence of the resolution of the DEM in the extraction of the drainage network of watersheds using multifractal analysis. The authors tested three DEM resolutions in four river basins with different levels of drainage network distribution, aiming to find the most adequate value of the accumulated flow threshold. They observed that the limit value of adequate flow accumulation increases as the DEM resolution increases and shows a greater variability for basins with lower drainage densities.

Issues related to the scale, precision and sensitivity of DEM data, too, were studied by Das et al. (2016). The authors individually extracted and analyzed the relief, surface area, size, shape and properties of a river basin in a mountainous region from the following DEMs: derived from Advanced Spaceborne Thermal Emission and Reflection Radiometer (ASTER V2), Shuttle Radar Topography Mission (SRTM V4, C-Band, 3 arc-second), Cartosat-1 (CartoDEM 1.0) and topographical maps (R.F. 1:250,000 and 1:50,000). The authors observed that DEMs derived from the 1: 50,000 topographic map and ASTER V2 data are more accurate and consistent in terms of absolute accuracy than the other DEM data products generated or available, based on the morphometric parameters extracted from each.

Cecílio et al. (2013), also in mountainous conditions, evaluated the precision of DEMs for the automatic delineation of a river basin. The DEMs evaluated originated from radar images (SRTM) and spatial interpolation of contours (1:50,000 scale), with a spatial resolution of $10 \mathrm{x}$ $10 \mathrm{~m}$. The authors verified that the DEM generated from the contour lines and hydrographic mapped using the interpolator Top To Raster presented the best performance of representation of relief of the basin. Oliveira et al. (2010) found little significant differences for most morphometric characteristics when comparing Shuttle Radar Topography Mission (SRTM) data with data of topographic maps on a scale of 1:100,000; however, they recommended the comparison of the hydrography obtained from SRTM data with those obtained from remote sensing data or topographic maps.

Other studies on the evaluation of DEMs, with objectives different from those presented previously, can also be found in the literature, such as that of Chagas et al. (2010), which compared different DEMs (resolution of $30 \times 30 \mathrm{~m}$ ) for application in a digital mapping of soils. Qualitative analysis identified that the DEM obtained from topographic maps presented superior quality to the DEMs derived from remote sensors, since these resulted in errors that could compromise the relations between attributes of the terrain and the conditions of the soils.

Although many studies on evaluation of DEMs have already been made, with different objectives, analysis has not been verified in the determination of the morphometric characteristics of basins in conditions of transition of reliefs. Close to the above, the study by Chaplot et al. (2006) evaluated the accuracy of interpolation techniques to obtain DEMs in flat (western France) and mountainous (northern Laos) areas in conditions of microplots, slopes and catchment with different sample density of altitude. In this work, the authors evaluated the precision of the techniques to the determination of altitude, observing few differences between 
them when the sampling density was high. However, they stressed the importance of performing other studies that evaluate the quality of the DEM in attributes more sensitive to the interpolation technique selection than the altitude itself, such as: slope angle, slope curvature, drainage network and catchment boundaries, because many GIS applications depend on them.

Thus, the objective of this study was to evaluate the performance of different DEMs to obtain morphometric characteristics of a river basin located in a transition region between the reliefs São Francisco plateau, São Franciscana depression and Espinhaço Range, aiming to give subsidies for hydrological studies at the site. In the sequence, the methodology used in the work is presented, highlighting the form of obtaining the DEMs and of the morphometric characteristics, the main results obtained and discussions, besides the main conclusions reached with the research.

\section{MATERIALS AND METHODS}

\subsection{Study area}

The study was conducted in the Peixe River Basin, which has a drainage area of approximately $580 \mathrm{~km}^{2}$. Located in the central region of the State of Minas Gerais, Brazil, between the coordinates $19^{\circ} 25^{\prime} 00^{\prime \prime}$ and $19^{\circ} 42^{\prime} 00^{\prime \prime} \mathrm{S}$ and $44^{\circ} 40^{\prime} 00^{\prime \prime}$ and $45^{\circ} 00^{\prime} 00^{\prime \prime} \mathrm{W}$, in one of the most important river basins in the country, the São Francisco River Basin, the basin of the Peixe River has transition between the reliefs São Francisco plateau, São Franciscana depression and Espinhaço Range (Figure 1).

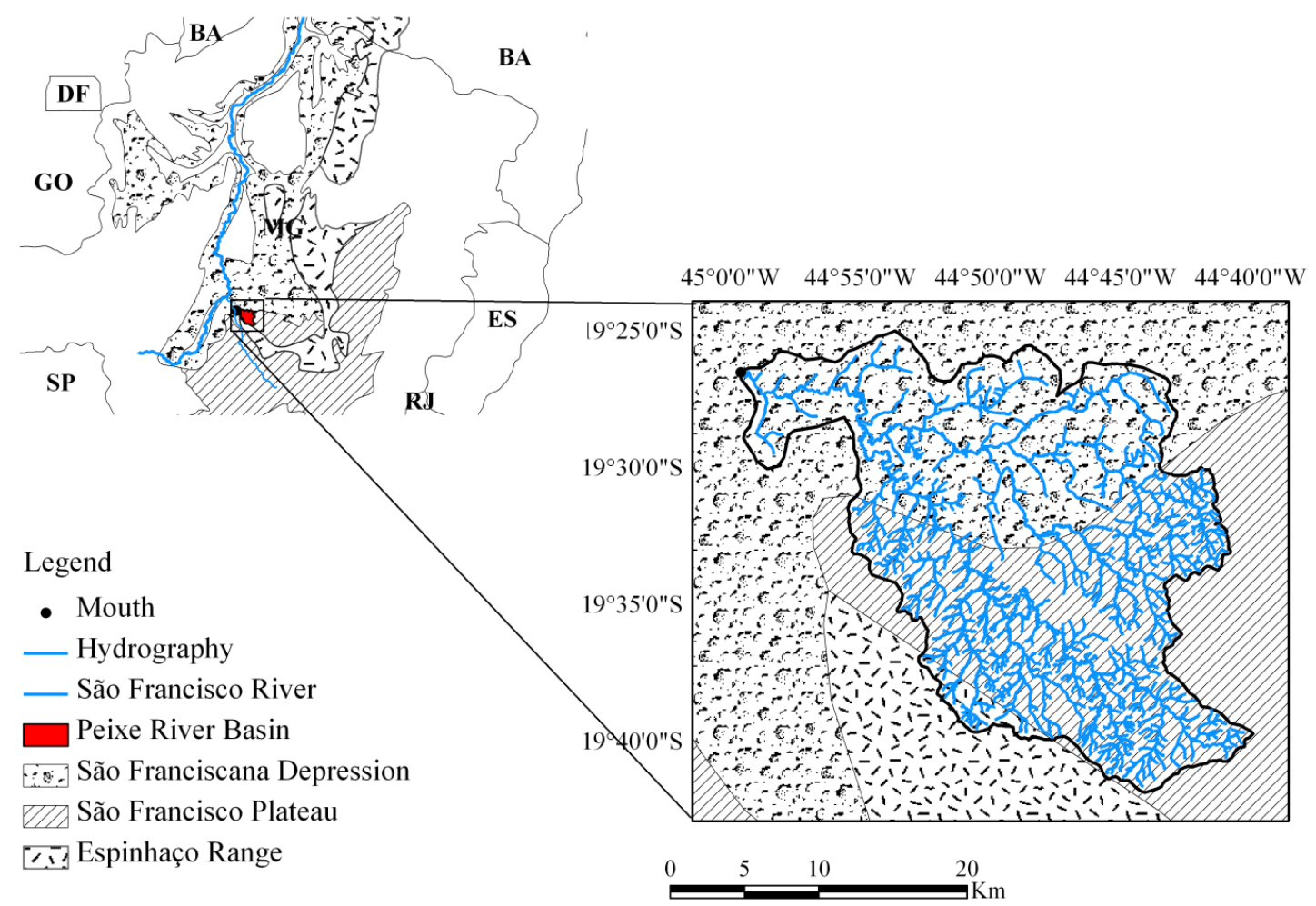

Figure 1. Location of study area.

The São Francisco plateau is composed of tabular surfaces called "chapadas", which are intersected by the headwaters of deepened draining. The relief is distinguished in two levels of altitudes, ranging of 800 to $1000 \mathrm{~m}$ and 600 to $800 \mathrm{~m}$. The São Franciscana depression develops along the drainage of the São Francisco River, where the prevailing forms of relief flattened with altitudes around $500 \mathrm{~m}$ (IGA, 2016). The Espinhaço Range is a large hydrographic splitter 
interposed between the basins of east-central Brazilian and of São Francisco River, and it constitutes, in Minas Gerais State, a set of highlands, with predominance of ridges, peaks, valleys embedded and to a lesser extent the forms slightly wavy (Sodré et al., 2007).

The climate of the region is Cwa, mesothermal tropical type, according to the classification of Köppen (Köppen and Geiger, 1936), presenting dry winters and mild summers with the average coldest month below $19^{\circ} \mathrm{C}$. The predominant vegetation type is cerrado of medium size, with patches of evergreen forests and subcaducifólias (Romano and Soares, 2007). The soils present in the basin are: Red Latosols; Red Yellow Latosols; Red Argisol and Red Yellow Argisols (IBGE, 2001).

\subsection{Obtaining and processing of data}

This study used five DEMs, three generated from the data of the SRTM and two others obtained from the topographic maps (CT).

The SRTM data were obtained from the Brazilian Agricultural Research Corporation (EMBRAPA), with a spatial resolution of $90 \times 90 \mathrm{~m}$ and WGS84 reference ellipsoid. The topographical maps used were the sheets Para de Minas (042533) and Pompeu (042495), made available by the Brazilian Institute of Geography and Statistics (IBGE), in vector format on a scale of 1:100,000, represented by contour lines equally spaced of $50 \mathrm{~m}$, altitude data and hydrography. The processing of data and the obtaining of the morphometric characteristics were performed using ArcGIS ${ }^{\circledR} 9.3$ (ESRI, 2008).

\subsubsection{SRTM-DEMs}

The SRTM DEMs were composed of one elaborated from the original matrix (SRTM-O) and two from the refinement of the original data. To generate the DEMs refined, SRTM data have been modified for the vector format (level curves with equidistance of $20 \mathrm{~m}$ ) and, subsequently, the level curves were interpolated by means of the interpolator Top To Raster with and without the support of the mapped hydrography, generating, respectively, the SRTMTRH and SRTM-TR DEMs, both with a spatial resolution of $10 \times 10 \mathrm{~m}$.

For the delineation of the basin and, subsequently, obtaining the morphometric characteristics, the data of the DEMs were processed following the steps: fill of the spurious depressions (fill sinks); direction of flow (flow direction); accumulated flow (flow accumulation) and delineation of basins (watershed). It should be emphasized that the hydrography was generated from the accumulated flow, using the Raster Calculator tool of the extension Spatial Analyst of ArcGIS ${ }^{\circledR}$ 9.3, using a value of 500 (a value that provided a more representative hydrography) as the minimum number of cells for the generation of flow.

\subsubsection{CT-DEMs}

The preparation of the DEMs from topographic maps was performed by means of interpolation of the level curves using the interpolator Top To Raster with and without the support from mapped hydrography, generating, respectively the CT-TRH and CT-TR DEMs, both with a spatial resolution of $10 \times 10 \mathrm{~m}$.

For the delineation of the basin and, subsequently, the obtaining of morphometric characteristics from CT-DEMs, their data were processed by following the same steps described previously for the SRTM-DEMs.

\subsection{Morphometry of the river basin}

From each DEM (obtained from SRTM data or topographic maps) the following morphometric characteristics of the basin were obtained: drainage area; perimeter; compactness coefficient; form factor; circularity index; slope; altitude; length of the main river, density of drainage and the order of water courses. 
The drainage area of a basin is defined as the flat area bounded by the topographic divider, which in turn defines the perimeter of the same. The compactness coefficient $\left(\mathrm{K}_{\mathrm{c}}\right)$, the form factor $(F)$, the circularity index (IC) and the density of drainage $\left(D_{d}\right)$ were obtained with the Equation 1, 2, 3 and 4, respectively.

$$
\begin{aligned}
& K_{C}=0,28 \cdot \frac{P}{\sqrt{A}} \\
& F=\frac{A}{L^{2}} \\
& \mathrm{IC}=12,57 \cdot \frac{A}{P^{2}} \\
& D_{d}=\frac{L_{t}}{A}
\end{aligned}
$$

In that:

$$
\begin{aligned}
& \mathrm{K}_{\mathrm{c}} \text { - compactness coefficient (dimensionless); } \\
& \mathrm{P} \text { - perimeter of the basin }(\mathrm{km}) \text {; } \\
& \text { A - area of the basin }\left(\mathrm{km}^{2}\right) \text {; } \\
& \mathrm{F} \text { - form factor (dimensionless); } \\
& \mathrm{L} \text { - shaft length of the basin }(\mathrm{km}) \text {; } \\
& \mathrm{IC} \text { - circularity index (dimensionless); } \\
& \mathrm{D}_{\mathrm{d}} \text { - density of drainage }\left(\mathrm{km} \mathrm{km}^{-2}\right) \text {; } \\
& \mathrm{L}_{\mathrm{t}} \text { - total length of water courses }(\mathrm{km})
\end{aligned}
$$

The compactness coefficient relates the form of the basin to a circle and closer values to 1 is indicative of the potential for flood flows. The form factor $(\mathrm{F})$ relates the shape of the basin to a rectangle. A narrow and long basin (small value of $\mathrm{F}$ ) is less prone to flooding than another with the same area, but with larger value of $F$. This is due to the less occurrence of intense rainfall covering at the same time the entire extension of a basin with narrow and long formato (Oliveira et al., 2010). According to Schumm (1956), the circularity index (IC) lower than 0.51, indicates that the basin tends to be more elongated favoring runoff; IC equal to 0.51 indicates a moderate level of runoff and IC greater than 0.51 indicates that the basin tends to be more circular, favoring the occurrence of flooding.

To obtain data of slope, we used the function slope available in extension Spatial Analyst of ArcGIS ${ }^{\circledR}$ 9.3. The hydrographic network was ordered according to Strahler (1957).

\subsection{Performance evaluation of DEMs}

The assessment of DEMs was performed in a quantitative and qualitative form. The quantitative evaluation consisted in determining the percentage errors between the values of the morphometric characteristics determined with the DEMs and those obtained by means of topographic maps, called reference (REF), as Oliveira et al. (2010). The qualitative evaluation consisted in comparing the mapped hydrography with the numeric hydrography and in the comparison between the delineation of the basin obtained with the DEMs and those bounded manually in topographic maps (REF), as with Chagas et al. (2010) and Cecílio et al. (2013). It should be emphasized that, due to the fact that the work focuses on the determination and evaluation of the morphometric characteristics of the basin obtained from different DEMs, the evaluation methodology described is sufficient and no other statistical measures are necessary, since the vertical accuracy of DEMs was not evaluated. 


\section{RESULTS AND DISCUSSION}

Table 1 shows the results of the morphometric characterization of the Peixe River Basin, obtained from DEMs evaluated and of reference (REF).

Table 1. Results of the morphometric characterization of the Peixe River Basin.

\begin{tabular}{|c|c|c|c|c|c|c|c|c|c|c|c|}
\hline \multirow{2}{*}{$\begin{array}{l}\text { Morphometric } \\
\text { characteristic }\end{array}$} & \multirow{2}{*}{ REF } & \multicolumn{2}{|c|}{ SRTM-O } & \multicolumn{2}{|c|}{ SRTM-TR } & \multicolumn{2}{|c|}{ SRTM-TRH } & \multicolumn{2}{|c|}{ CT-TR } & \multicolumn{2}{|c|}{ CT-TRH } \\
\hline & & Value & DIF (\%) & Value & DIF $(\%)$ & Value & DIF $(\%)$ & Value & $\operatorname{DIF}(\%)$ & Value & DIF (\%) \\
\hline $\mathrm{A}\left(\mathrm{km}^{2}\right)$ & 578.81 & 683.80 & 18.14 & 685.60 & 18.45 & 581.02 & 0.38 & 732.99 & 26.64 & 572.35 & 1.12 \\
\hline $\mathrm{P}(\mathrm{km})$ & 141.44 & 134.33 & 5.03 & 148.23 & 4.80 & 149.46 & 5.67 & 159.90 & 13.05 & 158.14 & 11.81 \\
\hline $\mathrm{L}(\mathrm{Km})$ & 80.05 & 58.62 & 26.77 & 61.74 & 22.87 & 85.71 & 7.07 & 52.53 & 34.38 & 75.82 & 5.28 \\
\hline $\mathrm{L}_{\mathrm{t}}(\mathrm{km})$ & 801.24 & 250.18 & 68.77 & 1502.96 & 87.58 & 1.354 .80 & 69.09 & 1.671 .81 & 108.65 & 1.197.38 & 49.44 \\
\hline $\mathrm{K}_{\mathrm{c}}$ & 1.65 & 1.44 & 12.73 & 1.59 & 3.64 & 1.74 & 5.45 & 1.65 & 0.00 & 1.85 & 12.12 \\
\hline $\mathrm{F}$ & 0.09 & 0.20 & 122.22 & 0.18 & 100.00 & 0.08 & 11.11 & 0.27 & 200.00 & 0.10 & 11.11 \\
\hline IC & 0.36 & 0.48 & 33.33 & 0.39 & 8.33 & 0.33 & 8.33 & 0.36 & 0.00 & 0.29 & 19.44 \\
\hline $\mathrm{D}_{\mathrm{d}}\left(\mathrm{km} \mathrm{km}^{-2}\right)$ & 1.38 & 0.37 & 73.19 & 2.19 & 58.70 & 2.33 & 68.84 & 2.28 & 65.22 & 2.09 & 51.45 \\
\hline Order & 6 & 4 & - & 7 & - & 7 & - & 7 & - & 7 & - \\
\hline $\mathrm{A}_{\max }(\mathrm{m})$ & 1200 & 1214 & 1.17 & 1218 & 1.50 & 1215 & 1.25 & 1225 & 2.08 & 1223 & 1.92 \\
\hline$A_{\min }(m)$ & 600 & 611 & 1.83 & 610 & 1.67 & 601 & 0.17 & 579 & 3.50 & 593 & 1.17 \\
\hline Average slope (\%) & 7.52 & 7.15 & 4.92 & 9.05 & 20.35 & 7.96 & 5.85 & 5.14 & 31.25 & 7.52 & 0.00 \\
\hline
\end{tabular}

A - drainage area; $\mathrm{P}$ - perimeter; $\mathrm{L}$ - length of the main river; $\mathrm{L}_{\mathrm{t}}$ - total length of water courses; $\mathrm{K}_{\mathrm{c}}$ - compactness coefficient; $\mathrm{F}$ - form factor; IC - circularity index; $D_{d}$ - density of drainage; $A_{\max }$ - maximum altitude, $A_{\min }$ - minimum altitude. 
Based on values obtained for the morphometric characteristics $K_{c}, F$ and IC (Table 1), the Peixe River Basin is classified as elongated trend and of low susceptibility to the occurrence of floods in normal conditions of precipitation, once it presented $\mathrm{K}_{\mathrm{c}}$ away from unity $\left(\mathrm{K}_{\mathrm{c}}\right.$ greater than 1.4), small values of $F$ (ranging from 0.08 to 0.27 ) and values of IC smaller than 0.51 .

With regard to the differences in estimates of the morphometric characteristics mentioned above, between the DEMs and the REF, it is observed for $\mathrm{K}_{\mathrm{c}}$ that these ranged from $0 \%$ (CTTR) to $12.73 \%$ (SRTM-O). How much to index F, the differences were of $11.11 \%$ (SRTMTRH and CT-TRH) to 200\% (CT-TR) and for IC of 0\% (CT-RT) to 33.33\% (SRTM-O). Both the differences are in absolute values.

These three indexes lead to the same classification of the shape of the basin, which is elongated trend. However, there were differences between the values obtained from DEMs and the REF (Table 1), which in some cases were significant. Analyses of the performance of the models based on these indices are not advisable, since they involve other morphometric characteristics in their determination and wrong conclusions can made. This is evident in the present study, when we observe differences of $0 \%$ in $\mathrm{K}_{\mathrm{c}}$ and IC with the CT-TR in comparison to the REF; however, this does not depict the performance of the model, since the variables involved in determining these indices, which is the drainage area and the perimeter of the basin, were not properly estimated (Table 1).

With respect to the drainage area, the models in the study that had the support of the mapped hydrographic at the time of their generation (SRTM-TRH and CT-TRH) showed small differences in estimates in relation to those calculated from the delineation of reference (REF), of 0.38 and $1.12 \%$, respectively, in absolute values (Table 1). For the models that did not use the mapped hydrographic as support at the time of their generation (SRTM-O, SRTM-TR and CT-TR), overestimates of greater magnitude in the drainage area are observed, of 104.99 (SRTM-O), 106.79 (SRTM-TR) and $154.18 \mathrm{~km}^{2}$ (CT-TR) in relation to the REF, which resulted in percentage differences of $18.14,18.45$ and 26.64, respectively (Table 1). The poor performance of these models in the determination of the drainage area becomes obvious when one observes the delineation of the Peixe River Basin obtained from different DEMs compared to that obtained manually (REF) (Figure 2).
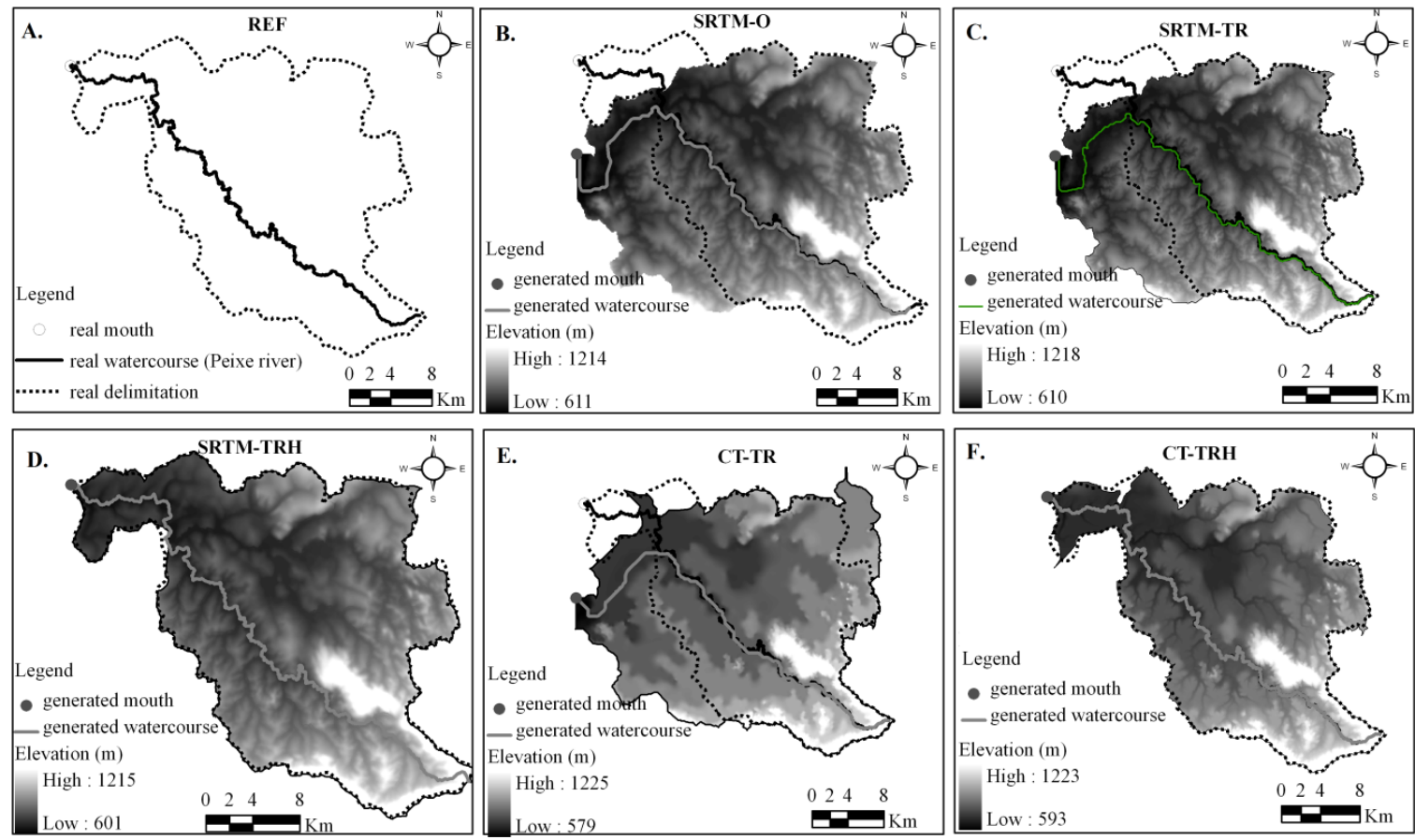

Figure 2. Delineation of the Peixe River Basin (A) manual; (B), (C) and (D) from SRTM data; and (E) and (F) from topographical maps. 
It turns out that the delineation of the basin using the DEMs (SRTM and topographic maps) that had the mapped hydrography as support at the time of their generation (Figures 2D and 2F) proved to be compatible with the manual delineation obtained from topographic maps (Figure 2A). By means of this qualitative analysis and, also, in the quantitative analysis shown in Table 1, the SRTM-TRH and CT-TRH DEMs showed great performance in the delineation of the basin and in the determination of the drainage area, important attributes for hydrologic studies. On the other hand, the delineation obtained with the DEMs generated from SRTM data and topographic maps that did not have the support of the mapped hydrographic (Figures $2 \mathrm{~B}, 2 \mathrm{C}$ and $2 \mathrm{E}$ ) was not compatible with the manual delineation, and so had the biggest mistakes in the estimation of the drainage area (Table 1).

This is not compatible with SRTM-O, SRTM-RT, and CT-RT DEMs on the delineation of the basin are mainly associated with a deviation of the main water course, the Peixe River, to a nearby basin with consequent generation of a mouth entirely off the actual location, as can be seen in Figures 2B, 2C and 2E. Alcaraz et al. (2009) also had problems similar to those of the study to delineate a watershed with greater variation of reliefs with the SRTM DEM, which led to an error of joining in the drainage network and generation of the mouth outside of location, greatly increasing the drainage area of the basin.

This fact also interfered directly in the characteristics of the drainage network, in particular, on the length of the main river (L), for the which differences were observed in estimates of 26.77, 22.87 and $34.38 \%$ in comparison to the real (REF) with the use of SRTM-O, SRTM-TR, CT-RT DEMs, respectively (Table 1). In the face of these analyses (qualitative and quantitative), these models are inadequate to determine the main morphometric characteristics of the basin used in hydrological studies, which, if they are used for this purpose, will compromise the output results.

It is interesting to note that the Peixe River Basin is inserted in a transition region between the reliefs São Francisco plateau, São Franciscana depression and Espinhaço Range, which have distinct characteristics and striking geology and topography. The São Franciscana depression is a region that develops along the banks of the São Francisco River with predominance of extensive low-lying areas of plan relief. It is in this region that the biggest problems occurred with the DEMs, especially those that did not have the support of the mapped hydrography at the time of their generation (SRTM-O, SRTM-TR and CT-TR), because they failed in adequately represent the course of the main river, in addition to the generation of many tributaries watercourses (Figure 3).

As can be seen in Figure 3, in the region of São Franciscana depression courses of tributaries water were generated in excess for all DEMs evaluated, except for the SRTM-O. This review helps explain the overestimates found in the comparison of the total length of water courses (Lt) obtained with the DEMs and the REF, which ranged from $49.44 \%$ (CT-TRH) to $108.65 \%$ (CT-TR), with the exception of the SRTM-O what underestimated at $68.77 \%$. These overestimates are associated with the spatial resolution used, which was $10 \mathrm{x} 10 \mathrm{~m}$ for all DEMs, except for the SRTM-O $(90 \times 90 \mathrm{~m})$, which allowed the formation of many rectilinear watercourses in flat areas, due to the nature of this region that makes it difficult to represent its drainage system. This is easily seen, because the reliefs of the Sao Francisco Plateau and the Espinhaço Range have areas with very steep slopes and the hydrography generated represented the actual area well in DEMs SRTM-TRH and CT-TRH (Figure 3C and 3E). The generation of many rectilinear watercourses in flat areas with the use of DEMs is also highlighted by Seyler et al. (2009) and Cecílio et al. (2013).

In the region of the São Franciscana Depression, the SRTM-TRH and CT-TRH DEMs have provided the formation of tributaries channels tin relation to hydrography of reference (REF); the main water courses were well represented (Figures 3C and 3E), as can be verified 
by the small difference between the length of the main river obtained with the DEMs in relation to the REF, which was 7.07 and $5.28 \%$ for the SRTM-TRH and CT-TRH, respectively.

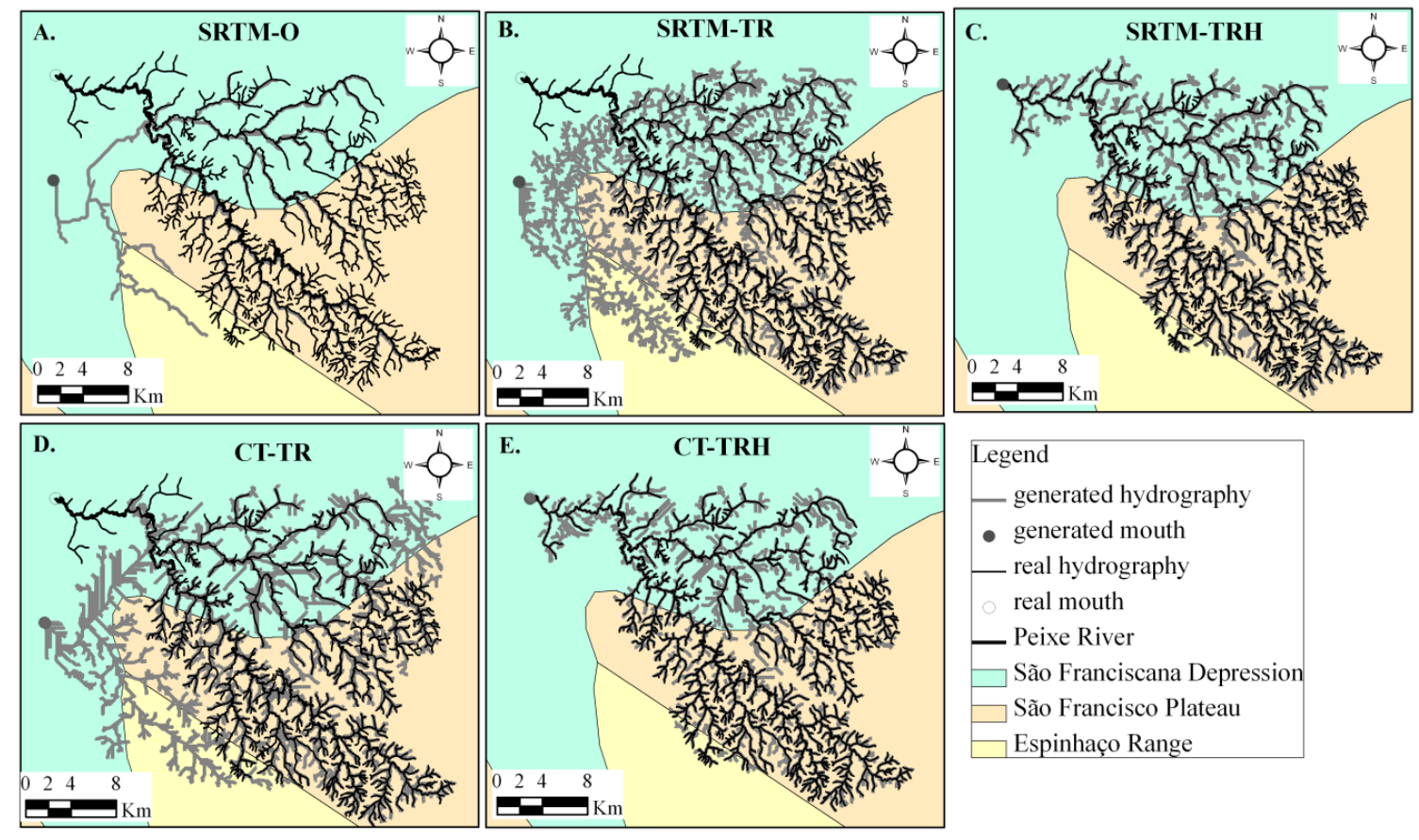

Figure 3. Mapped hydrography of the Peixe River Basin and those obtained by means of the DEMs: SRTM-O (A); SRTM-TR (B); SRTM-TRH (C); CT-TR (D) and CT-TRH (E).

The biggest problem with the representativeness of the hydrography in the region of the São Franciscana depression was the diversion of the main river (Peixe river) to a nearby basin, as previously discussed. However, it is worth noting that this happened with those models that did not have the support of the mapped hydrography during their generation (Figures 3A, 3B and 3D), which allows us to conclude that for the generation of DEMs for a region or even for other regions with similar characteristics, it is necessary to use the mapped hydrography as support, either from SRTM data or topographical maps. Some authors, such as Pires et al. (2005) and Cecílio et al. (2013) also suggest that, in order to force the location of the drainage network of a basin, which also has been observed in studies of hydrologic modeling (Pereira et al. 2016a; 2016b).

Comparing the values of $\mathrm{D}_{\mathrm{d}}$ obtained by methods in the present study, we observed significant variation in relation to the reference being of $51.45 \%$ (CT-TRH) to $73.19 \%$ (SRTM$\mathrm{O})$, which is explained by the difference between the total length of watercourses obtained with the DEMs and reference, which also explains the difference between the order of the basin obtained by reference and by DEMs.

Finally, analyzing the characteristics related to relief, good estimates were obtained of the minimum and maximum altitudes through all DEMs in comparison with the REF, with maximum differences of 2.08 and 3.50\%, respectively, for the CT-TR (Table 1). With respect to the average slope of the basin, close values were obtained (differences in about $5 \%$ ) between the SRTM-O and SRTM-TRH and the reference, which in this case was the slope obtained with the CT-TRH DEM, due to the same have been derived from topographical maps. The greatest error observed in determining the average slope of the basin was with the CT-TR DEM, whose value was $31.25 \%$ (Table 1). Figure 4 shows the data of slopes obtained from different DEMs evaluated. 

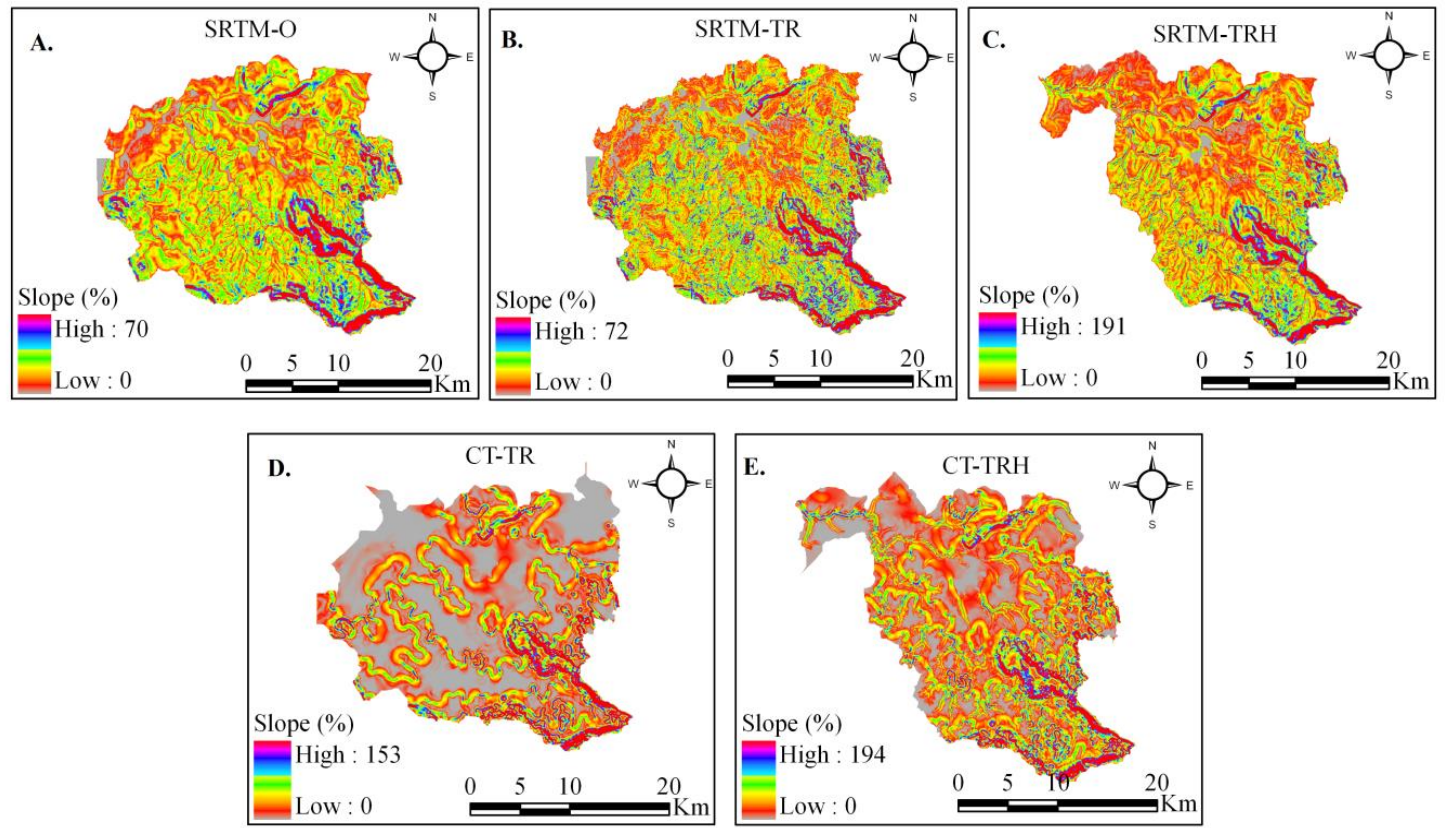

Figure 4. Slope of the Peixe River Basin determined from different DEM.

A degree of detail in the SRTM data (Figures 4A, 4B and 4C) in relation to the data of topographical maps (Figure 4D and 4E) can be observed in Figure 4. Results similar to this were obtained by Oliveira et al. (2010) when comparing DEMs from SRTM and topographical maps. They concluded that this difference is due to the greater detail from SRTM in flat areas, which can also be found in the present study when comparing Figures 4A, 4B and 4C with the Figures 4D and 4E, where areas considered of slope zero in Figure 4D and 4E are represented with details of slope in Figures 4A, 4B and 4C. However, it is important to note that the scale of the topographic maps used was 1:100,000, and it is interesting to carry out other studies using maps with different scales, for example 1:50,000, so that a better conclusion can be reached on the level of detailing of DEMs obtained from topographic maps, in comparison to remote sensing data (for example SRTM), regarding slope characterization.

\section{CONCLUSIONS}

Based on the objective of the research, which was to evaluate the performance of different DEMs for the morphometric characterization of the Peixe River Basin, which is inserted in a transition region between the Reliefs Planalto São Franscisco, São Fransciscana Depression and Serra do Espinhaço, we can conclude that:

i) In general, the DEMs that used the mapped hydrography as support at the time of their generation (SRTM-TRH and CT-TRH) presented excellent performance and are indicated for on-site study, and those that did not use (SRTM-O; SRTM -TR and CT-TR) presented poor performance.

ii) The DEMs, SRTM-O, SRTM-TR and CT-TR, provided the incorrect generation of hydrography in the region of the São Franciscana Depression (flat region), observed by the diversion of main river and generation of the mouth in another basin, causing significant errors in the determination of the morphometric characteristics of the basin, mainly in the drainage area and length of the main river, which varied from 18.1 to $26.6 \%$ and 26.7 to $34.4 \%$, respectively.

iii) The study was performed using 1:100,000 topographic maps and SRTM images at 90 x $90 \mathrm{~m}$ resolution, and the results make clear the importance of evaluating DEMs prior to their use in river basin studies, which is not always the case. However, further studies using 
topographic maps and SRTM (or other remote sensor) images at higher scales are recommended to provide a more solid conclusion on the performance of DEMs in this transition region between the São Francisco Plateau, São Francisco Depression and Espinhaço Range reliefs.

\section{ACKNOWLEDGEMENTS}

The authors would like to thank FAPEMIG by the financial support to the research project "Generation of hydrographically conditioned digital elevation model for environmental studies in the Pará river basin - MG" performed by the program PROBIC, from which originated the work.

\section{REFERENCES}

ABDULKAREEM, J. H.; PRADHAN, B.; SULAIMAN. W. N. A.; JAMIL, N. R. Quantification of Runoff as Influenced by Morphometric Characteristics in a Rural Complex Catchment. Earth Systems and Environment, v. 2, p. 1-18, 2018. https://doi.org/10.1007/s41748-018-0043-0

AHER, P. D.; ADINARAYANA, J.; GORANTIWAR, S. D. Quantification of morphometric characterization and prioritization for management planning in semi-arid tropics of India: a remote sensing and GIS approach. Journal of Hydrology, v. 511, p. 850-860, 2014.

ALCARAZ, S. A.; SANNIER, C.; VITORINO, A. C. T.; DANIEL, O. Comparison of methodologies for automatic generation of limits and drainage networks for hydrographic basins. Revista Brasileira de Engenharia Agrícola e Ambiental, v. 13, n. 4, p. 369375, 2009. http://dx.doi.org/10.1590/S1415-43662009000400001

AMERI, A. A.; POURGHASEMI, H. R.; CERDA, A. Erodibility prioritization of subwatersheds using morphometric parameters analysis and its mapping: A comparison among TOPSIS, VIKOR, SAW, and CF multi-criteria decision making models. Science of The Total Environment, v. 613, p. 1385-1400, 2018.

ARIZA-VILLAVERDE, A. B.; JIMÉNEZ-HORNERO, F. J.; DE RAVÉ, E. Gutiérrez. Influence of DEM resolution on drainage network extraction: A multifractal analysis. Geomorphology, v. 241, p. 243-254, 2015.

BASSIOUNI, M.; VOGEL, R. M.; ARCHFIELD, S.A. Panel regressions to estimate low-flow response to rainfall variability in ungauged basins. Water Resources Research, v. 52, n. 12, p. 9470-9494, 2016.

CECÍLIO, R. A.; COUTINHO, L. M.; XAVIER, A. C.; MOREIRA, M. C.; ZANETTI, S. S.; GARCIA, G. O. Delimitação de bacia hidrográfica em região montanhosa a partir de diferentes modelos digitais de elevação. Semina: Ciências Agrárias, v. 34, n. 5, p. 2007 2024, 2013. http://dx.doi.org/10.5433/1679-0359.2013v34n5p2007

CHAGAS, C. S.; FERNANDES FILHO, E. I.; ROCHA, M. F.; CARVALHO Jr., W.; SOUZA NETO, N. C. Avaliação de modelos digitais de elevação para aplicação de um mapeamento digital de solos. Revista Brasileira de Engenharia Agrícola e Ambiental, v. 14, n. 2, p. 218-226, 2010.

CHAPLOT, V.; DARBOUX, F.; BOURENNANE, H.; LEGUÉDOIS, S.; SILVERA, N.; PHACHOMPHON, K. Accuracy of interpolation techniques for the derivation of digital elevation models in relation to landform types and data density. Geomorphology, v. 77, n. 1-2, p. 126-141, 2006. http://dx.doi.org/10.1016/j.geomorph.2005.12.010 
CUNHA, E. R.; BACANI, V. M. Morphometric Characterization of a Watershed through SRTM Data and Geoprocessing Technique. Journal of Geographic Information System, v. 8, p. 238-247, 2016. http://dx.doi.org/10.4236/jgis.2016.82021

DAS, S.; PATEL, P. P.; SENGUPTA, S. Evaluation of different digital elevation models for analyzing drainage morphometric parameters in a mountainous terrain: a case study of the Supin-Upper Tons Basin, Indian Himalayas. SpringerPlus, v. 5, n. 1, p. 1544, 2016.

ENVIRONMENTAL SYSTEMS RESEARCH INSTITUTE - ESRI. ArcGIS Professional GIS for the desktop. version 9.3. Software. Redlands, 2008.

ESPER ANGILLIERI, M. Y. Morphometric analysis of Colangüi river basin and flash flood hazard, San Juan, Argentina. Environmental Geology, v. 55, n. 1, p. 107-111, 2008. http://dx.doi.org/10.1007/s00254-007-0969-2

FIOREZE, A. P.; OlIVEIRA, L. F. C. de; FRANCO, A. P. B. Avaliação do desempenho de equações de regionalização de vazões na bacia hidrográfica do Ribeirão Santa Bárbara, Goiás, Brasil. Revista Ambiente \& Água, v. 3, n. 2, p. 62-76, 2008. http://dx.doi.org/10.4136/ambi-agua.53

GEBREHIWOT, S. G.; IISTEDT, U.; GÄRDENAS, A. I.; BISHOP, K. Hydrological characterization of watersheds in the Blue Nile Basin, Ethiopia. Hydrology and Earth System Sciences, v. 15, n. 1, p. 11-20, 2011. http://dx.doi.org/10.5194/hess-15-11-2011

INSTITUTO BRASILEIRO DE GEOGRAFIA E ESTATÍSTICA - IBGE. Mapa de Solos do Brasil. 2001. Disponível em: ftp://geoftp.ibge.gov.br/mapas_tematicos/mapas_murais/solos.pdf. Acesso em: 17 jul. de 2015 .

INSTITUTO DE GEOCIÊNCIAS APLICADAS. Atlas digital de minas gerais: Geomorfologia. Disponível em: http://www.iga.mg.gov.br/mapserv_iga/atlas/TutorialPDF/7-Geomorfologia.pdf. Acesso em: 20 de maio de 2016.

KÖPPEN, W.; GEIGER, R. Handbuch der klimatologie. Berlin: Gebrüder Borntraeger, 1936.

MERAJ, G.; ROMSHOO, S. A.; YOUSUF, A. R.; ALTAF, S.; ALTAF, F. Assessing the influence of watershed characteristics on the flood vulnerability of Jhelum basin in Kashmir Himalaya. Natural Hazards, v. 77, n. 1, p. 153-175, 2015.

MUDASHIRU, R. B.; SALAMI, A. W.; BILEWU, S. O. Evaluation of Methods of Peak Runoff Determination using Catchment Characteristics for Jere Sub-basin, Gurara River Basin, North Central Nigeria. The Journal of Engineering Research [TJER], v. 15, n. 1, p. 26-41, 2018.

OLIVEIRA, P. T. S.; ALVES SOBRINHO, T.; STEFFEN, J. L.; RODRIGUES, D. B. B. Caracterização morfométrica de bacias hidrográficas através de dados SRTM. Revista Brasileira de Engenharia Agrícola e Ambiental, v. 14, n. 8, p. 819-825, 2010.

PEREIRA, D. R.; MARTINEZ, M. A.; SILVA, D. D. da; PRUSKI, F. F. Hydrological simulation in a basin of typical tropical climate and soil using the SWAT Model Part II: Simulation of hydrological variables and soil use scenarios. Journal of Hydrology: Regional Studies, v. 5, p. 149-163, 2016a. http://dx.doi.org/10.1016/j.ejrh.2015.11.008 
PEREIRA, D. R.; MARTINEZ, M. A.; PRUSKI, F. F.; SILVA, D. D. Hydrological simulation in a basin of typical tropical climate and soil using the SWAT model part I: Calibration and validation tests. Journal of Hydrology: Regional Studies, v. 7, p. 14-37, 2006b. http://dx.doi.org/10.1016/j.ejrh.2016.05.002

PIRES, J. M.; NASCIMENTO, M. C.; SANTANA, R. M.; RIBEIRO, C. A. A. S. Análise da exatidão de diferentes métodos de interpolação para geração de modelos digitais de elevação e obtenção de características morfométricas em bacias hidrográficas. Revista Brasileira de Recursos Hídricos v. 10, n. 2, p. 39-47, 2005.

ROMAnO, A. W.; SOARES, A. C. P. Geologia da folha Pará de Minas SE.23-Z-C-IV: escala 1:100.000. Brasília; Belo Horizonte: CPRM/UFMG. 2007. Disponível em: http://rigeo.cprm.gov.br/xmlui/bitstream/handle/doc/10765/nota.pdf?sequence $=1$.

Acesso em: 10 de Nov. de 2016.

SEYLER, F.; MUlLER, F.; COCHONNEAU, G.; GUIMARÃES, L.; GUYOT, J. L. Watershed delineation for the Amazon sub-basin system using GTOPO30 DEM and a drainage network extracted from JERS SAR images. Hydrological Processes, v. 23, n. 22, p. 3173-3185, 2009. http://dx.doi.org/10.1002/hyp.7397

SCHUMM, S. A. Evolution of drainage systems and slopes in badlands at Perth Amboy, New Jersey. Geological society of America bulletin, v. 67, n. 5, p. 597-646, 1956. http://dx.doi.org/10.1130/0016-7606(1956)67[597:EODSAS]2.0.CO;2

SILVA, J. M. A.; PRUSKI, F. F.; SILVA, D. D. da; CECÍLIO, R. A. Metodologia para obtenção do hidrograma de escoamento superficial em encostas e canais. Parte I: desenvolvimento e avaliação. Engenharia Agrícola, v. 26, n. 3, p. 695-703, 2006. http://dx.doi.org/10.1590/S0100-69162006000300005

SODRÉ, R. V. R.; CARVALHO JÚNIOR, A. O.; MACHADO, W. P.; OLIVEIRA, S. N.; GOMES, R. A. T.; GUIMARÃES, R. F. Classificação de bacias de drenagem do Alto Jequitaí (Minas Gerais) a partir da análise de principais componentes e análise de grupos. Revista Brasileira de Geomorfologia, v. 8, n. 2, p. 73-86, 2007.

STRAHLER, A. N. Quantitative analysis of watershed geomorphology. Eos, Transactions

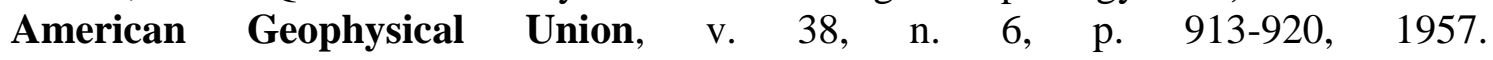
http://dx.doi.org/10.1029/TR038i006p00913

WOODROW, K.; LINDSAY, J. B.; BERG, A. A. Evaluating DEM conditioning techniques, elevation source data, and grid resolution for field-scale hydrological parameter extraction. Journal of Hydrology, v. 540, p. 1022-1029, 2016. 